\title{
THE GLOBAL AND THE LOCAL
}

\author{
GLOBALIZATION AND THE CONTRIBUTION \\ OF THE MEDIA ECONOMY TO A NATIONAL ECONOMY: \\ A CROSS-COUNTRY EMPIRICAL STUDY
}

\begin{abstract}
Xiaoqun Zhang and Alan B. Albarran
This study shows that the overall globalization index has a significant correlation with the percentage of media expenditures in GDP, while the social globalization index is a significant predictor for the percentage of media expenditures in GDP, after controlling for the economic, population, and social variables. These results suggest that globalization influences the contribution of the media economy to a national economy, and different dimensions of globalization have a varying level of influence. The results also suggest that the principle of relative constancy $(P R C)$ does not hold true when applied across countries, and globalization should be one of the explanatory variables that accounts for the variation of the contribution of media economy to national economy across countries.
\end{abstract}

Keywords: globalization, media economy, GDP, principle of relative constancy (PRC), cross-country.

As an essential part of an economic system - the media economy - makes a contribution to the national economy. This contribution can be measured by the percentage of media expenditures in GDP when GDP is calculated using the expenditure approach. Scholars have investigated expenditures for a long time. McCombs (1972) proposed the principle of relative constancy (PRC), which argues that the percentage of media expenditures in national income remains constant over time. The PRC has been tested by many scholars in and across various countries, and produced different findings. Many of these studies suggested that this percentage is influenced by multiple economic, political and social factors that characterize countries.

Globalization is one of the fundamental driving forces of contemporary societies that affects the development of the media economy (Albarran 2010), and thus, influences the contribution of the media economy to a national economy. The influence of globalization on the media economy was examined in previous studies (Chang and Chan-Olmsted 2005; Yang and Shanahan 2003). However, the authors used a proxy variable - economic openness - for globalization rather than direct measures of globalization. Moreover, the dependent variables used in these studies are the advertising expenditures and the penetration levels of media products, instead of the percentage of media expenditures in GDP. Thus, these studies did not directly investigate the contribution of media economy to national economy.

Journal of Globalization Studies, Vol. 9 No. 2, November 2018 32-49

DOI: 10.30884/jogs/2018.02.03 
Globalization is a complex process and possesses multiple dimensions (Clark 2000; Norris 2000; Keohane and Nye 2000). In the literature one can find several possible measures of globalization. Dreher, Gaston, Martens, and Boxem (2010) compared four globalization indexes using the criteria of relevance, robustness, added value, and transparency. Likewise, Zinkina, Korotayev, and Andreev (2013) compared six globalization indexes and analyzed their drawbacks. Although these two studies discussed the challenges and shortcomings of these indexes, they recognized the value of the measurement of globalization and proposed possible solutions, such as the collaborative work between quantitative experts and theoreticians and country-to-country network analysis. Moreover, the globalization indexes were used to study the relationships between globalization and economic and social issues, such as economic growth (Dreher 2006), the global financial economic crisis of 2008-2009 (Martens and Amelung 2010), income inequality (Mah 2002), democracy (Li and Reuveny, 2003), etc.

Following these empirical studies, this study examines the relationship between globalization and the percentage of media expenditures in GDP. The globalization index used in this study is the KOF Index of Globalization proposed by Dreher (2006), which is based on the definitions of globalization of Clark (2000) and Norris (2000) as well as the three-dimensional framework of Keohane and Nye (2000). This index measures the overall globalization, as well as the three dimensions - economic globalization, political globalization, and social globalization - of many countries in the world. It has been widely used by scholars to study globalization and its impacts on the contemporary world (e.g., Bergh and Nilsson 2010; Chang, Lee and Hsieh 2011; Ermini and Santolini 2014; Naatanen 2015).

\section{Literature Review}

Gross Domestic Product (GDP) and the Principle of Relative Constancy (PRC)

Gross Domestic Product (GDP) is the most comprehensive measure of economic performance. It is 'the market value of all final goods and services produced within an economy in a given period of time' (Mankiw 2007: 20). There are two approaches to calculate GDP. The expenditure approach sums expenditures by households, firms, the government, and foreign residents. The income approach sums the earnings of all production factors including wages, rents, and accruing profits (Samuelson 1964). As a part of an economy, the expenditures of mass media are included in the calculation of GDP. In particular, the consumption expenditures of households on mass media and the advertising expenditures of firms should be calculated in GDP when the expenditure approach is employed.

Media economists have been enchanted by the contribution of media industries to national economies. This contribution can be measured by the media revenue (from both consumers and advertisers) as a percentage of GDP. McCombs (1972) argued that a relative constant proportion of the available wealth will be devoted to media, known as the Principle of Relative Constancy (PRC). McCombs analyzed the money consumers and advertisers spent on mass media over a 40-year period (1929-1968). McCombs and Eyal (1980) further reinforced the support of the PRC hypothesis using data of an extended ten-year period (1968-1977) and reached similar findings. Wood (1986) tested the PRC using maximum-likelihood regression and data over a 60 -year period, and 
found support for the PRC. However, other studies have disagreed with the PRC. For example, Wood and O'Hare (1991) found that consumer spending on mass media increased dramatically during the 1980s. Son and McCombs (1993) found that consumer spending on mass media had increased both in absolute value and share of income during 1975-1987. The authors attributed this inconsistent finding to the rapid diffusion of new media during this period.

The media economists also tested PRC hypothesis using the data of other countries and reached mixed results. Werner (1986) found support for PRC using the Norwegians' media expenditure data from 1958-1982. Dupagne (1994) confirmed the PRC using the British people's media expenditure data from 1963-1989. Later, Dupagne (1997) showed the share of income spending on mass media increased considerably from 1970 to 1991 in Belgium. Kim (2003) demonstrated that the PRC was not supported in South Korea from 1961-1993. Picard (2001) and Van der Wurff, Bakker and Picard (2008) explored the relationship between advertising expenditures and GDP in developed countries, and found this relationship varied across countries. Chang and Chan-Olmsted (2005) examined the PRC using data of more than 70 countries from 1991-2001. The study found that the PRC hypothesis received more support in developed countries than developing countries. The authors further argued that the degree of applicability of the PRC depends on the characteristics of countries, such as economic and political conditions, and media systems.

\section{Globalization and the Media Economy}

Globalization is a value-laden concept that carries many different meanings and interpretations (Albarran 2010). Thus, scholars have proposed a variety of definitions, among which two have been widely used: Clark (2000) defined globalization as 'the process of creating networks of connections among actors at multi-continental distances, mediated through a variety of flows including people, information and ideas, capital and goods' (p. 86); Norris (2000) defined it as 'a process that erodes national boundaries, integrates national economies, cultures, technologies and governance and produces complex relations of mutual interdependence' (p. 155). Scholars argued that the economy - basically capitalism and international trade - is the primary incubator of globalization (e.g., Dreher, Gaston, and Martens 2008; Hardt and Negri 2000). Technological innovation, especially in the communication area, is the second primary engine (e.g., Dreher, Gaston, and Martens 2008; Langhorne 2001), while politics is the third primary driving force (e.g., Dreher, Gaston, and Martens 2008). Moreover, Keohane and Nye (2000) argue that globalization consists of three dimensions - economic globalization, political globalization, and social globalization.

Globalization is a critical driver in the media economy. For media firms and industries, the act of globalization occurs when companies reach beyond domestic borders to engage consumers in other nations. Originally, media globalization meant selling content around the world, a practice that first started with Hollywood films and expanded later to television programming. The United States is the largest exporter of media content in the world, leading to many concerns about the influence of America abroad and the notion of 'cultural imperialism' (Jayakar and Waterman 2000).

Globalization also occurs when companies acquire other properties in other countries. News Corporation began as an Australian newspaper company, acquiring news- 
papers in the United Kingdom and the United States before purchasing a group of television stations that would eventually become the Fox TV Network. News Corporation would later split into two companies, with the studios and networks becoming $21^{\text {st }} \mathrm{Cen}$ tury Fox. Japan-based Sony entered the film industry by first acquiring Columbia Tristar and later MGM.

Yet another form of globalization occurs when a company establishes multiple locations in other nations. Nielsen, a firm specializing in various types of research services, operates in over 100 countries throughout the world. Disney operates theme parks in several important global cities, and also has a strategic base in Latin America. Bertelsmann, the global leader in book publishing, has operations around the world through its various publishing entities.

Most companies seek to globalize to expand and grow their market share - a basic tenet of economic theory that a firm seeks to maximize its value for its owners and shareholders. Domestic markets in most developed countries are often fully developed and saturated. There is little room to expand market share except on an incremental basis (Anderson 2006). More opportunities for business growth and expansion may be found outside domestic borders. Millar, Choi and Chen (2005) place the media industries in the larger context of the cultural industries. The authors found that strong brands and intellectual assets associated with the film, music and media industries create a strong globalization 'pull' on the demand side, while production and global sourcing in turn provide a strong globalization 'push' on the supply side. These factors place the media industries in a unique position unlike other industries seeking to engage in globalization.

\section{Factors that Influence the Media Economy}

As argued by PRC, income is an important factor that influences media expenditures. For individuals or households, their media expenditures are restricted by their income budgets. When GDP is measured by the expenditure approach, individual/household expenditures consist of the biggest part of GDP (Rossana 2011). For companies, their advertising expenditures are also restricted by their revenue income. In the seminal study of PRC, McCombs (1972) demonstrated that the total spending on advertising was strongly correlated with consumer expenditures. A few studies support this argument (e.g., Ashley, Granger, and Schmalensee 1980; Duffy 1991; Quareles and Jeffres 1983).

The criticism of the PRC argues that income is only one of the variables that determine the demand for mass media (Lacy and Noh 1997). Scholars explored other economic variables that influence the media economy. Picard (2001) and Shaver and Shaver (2005) investigated the advertising expenditures in several European and Asian countries, and found that advertising declined during recession periods in general, while print media suffered more than electronic media. Other studies found a correlation between advertising expenditures and general economic performance (e.g., Swerdlow and Blessios 1993; Van der Wurff, Bakker, and Picard 2008). Schmalensee (1972) argued that economic growth influences advertising expenditures because many firms have a policy of 'fixing dollar advertising as a percentage of dollar sales' (p. 42). Studies also showed that most companies raise their budgets when the economy is recovering (e.g., Andras and Srinivasan 2003; Blank 1962). Two macroeconomic variables - real interest rate and unemployment - were also examined by economists regarding their influence 
on media expenditures (e.g., Burch and Gordon1984; Dupagne 1997; Grieves 1983; Mankiw 1985; Weber 1975).

Apart from economic variables, population variables are also factors that influence the media economy. In the early studies of the PRC, McCombs and colleagues suggested that the population variable could influence mass media spending (McCombs 1972; McCombs and Eyal 1980). Dupagne (1997) found total population was a better predictor for media spending than income. Chang and Chan-Olmsted (2005) used a total population variable as the predictor for advertising expenditures in a cross-national study. In the era of digital media, population density becomes a significant factor that influences digital media consumption as higher population density renders lower infrastructure investment. Studies provide empirical support for this theoretical argument (e.g., Faulhaber and Hogendorn 2000; Foros and Kind 2003; Gotz 2013; Valletti, Barros, and Hoernig 2002).

Urbanization and education are the other two variables that could influence media consumption. Park (1923) argued that urban residents depend heavily on other individuals and organizations, and thus, rely heavily on the media to meet their needs of daily lives. Demers (1994) used urbanization as one of the variables to create a structural pluralism index, and demonstrated this index predicted absolute changes in advertising expenditures. Moreover, it was argued that higher education level creates stronger demand of mass media (Delia 1987; Emery and Emery 1988). Empirical studies demonstrated that education level is associated with the penetration levels of both traditional media and digital media (e.g., Kraemer, Ganley, and Dewan 2005; Yang and Shanahan 2003).

\section{Cross-Country Studies of the Media Economy}

Several studies have considered the differences of the media economy across countries. Collins and Litman (1984) compared differences in program offerings and development between the Canadian cable industry and the U.S. cable industry, and concluded that a different economic status in each country, cultural peculiarities, and contrasting theories of regulation contributed to the differences. Goff (2002) reviewed broadband strategies of telecommunications operators in the United Kingdom, Spain, France, and Germany. Lee and Chan-Olmsted (2004) investigated the factors that have led to the differences in the development of broadband Internet in South Korea and the United States. Fan (2005) examined the regulatory factors that have affected the availability and affordability of Internet access in China and Australia. Sohn (2005) compared satellite broadcasting among the United States, Japan, the United Kingdom, and France. Yang and Shanahan (2003) examined the penetration level of multiple media products across more than 100 countries. Macleod (2004) studied the advertising expenditures on various media platforms in the United States, Japan, France, Kingdom, Germany, Canada and Italy.

\section{Research Hypotheses}

As previous cross-country studies suggest, media expenditures varied considerably across time and countries. Chang and Chan-Olmsted (2005) attributed this variation to the different characteristics of countries. Previous studies demonstrated that multiple variables could influence the media economy of a country, such as average income, GDP growth, real interest rate, unemployment, population, population density, urbani- 
zation, and education. The literature also argues that globalization and the media economy are closely related: globalization is strongly pushed by new media technologies, and globalization is a critical driver of the media economy since it facilitates the expansion of media markets globally. The current study attempted to conduct empirical research to examine the relationship between globalization and the contribution of media economy to a national economy. Based on the previous studies, the following hypotheses were put forth:

H1: Globalization indexes are positively correlated with the percentage of media expenditures in GDP.

H2: Globalization indexes are significant predictors for the percentage of media expenditures in GDP, after controlling for GDP per capita, GDP growth rate, real interest rate, unemployment rate, total population, population density, urban population, and education level.

\section{Methodology}

\section{Measures}

\section{Media economy}

The estimations of the entertainment and media industry value used to measure the media economy are drawn from PricewaterhouseCoopers (n.d.). PricewaterhouseCoopers evaluates the market value of various segments of entertainment and media industry across countries, and publishes these evaluations. The segments include Internet access, Internet advertising, TV subscription and licenses, TV advertising, recorded music, filmed entertainment, video games, magazine publishing, newspaper publishing, radio/out-of-home advertising, theme park and amusement parks, casino and other regulated gaming, educational book publishing, business-to-business publishing, and sports. Segment spending consists of advertising and direct end-user spending. The spending on hardware or on services that may be needed to access content is not included. In particular, in the television, radio, recorded music, filmed entertainment, and video game segments, the spending on television sets, radio sets, CD players or portable listening devices, DVD players, or video game consoles is not included. In the Internet segment, the spending on computers or on ordinary telephone lines is not included. In the box office component of filmed entertainment and in the gate revenue component of sports, the spending on food or other concessions is not included. The data on the media economy of 46 countries were obtained from PricewaterhouseCoopers annual report. The list of these countries is presented in Table 1. 
The list of countries whose data of media economy were obtained from PricewaterhouseCoopers

\begin{tabular}{|c|c|c|c|c|}
\hline United States & & & & \\
\hline EMEA & & & & \\
\hline $\begin{array}{l}\text { Western Europe } \\
\text { Austria } \\
\text { Belgium } \\
\text { Denmark } \\
\text { Finland } \\
\text { France } \\
\text { Germany }\end{array}$ & $\begin{array}{l}\text { Greece } \\
\text { Ireland } \\
\text { Italy } \\
\text { Netherlands } \\
\text { Norway } \\
\text { Portugal }\end{array}$ & $\begin{array}{l}\text { Spain } \\
\text { Sweden } \\
\text { Switzerland } \\
\text { United Kingdom }\end{array}$ & $\begin{array}{l}\text { Central and } \\
\text { Eastern Europe } \\
\text { Czech Republic } \\
\text { Hungary } \\
\text { Poland } \\
\text { Romania } \\
\text { Russia } \\
\text { Turkey }\end{array}$ & $\begin{array}{l}\text { Middle } \\
\text { East/Africa } \\
\text { Israel } \\
\text { Saudi Ara- } \\
\text { bia/Pan Arab } \\
\text { South Arab }\end{array}$ \\
\hline Asia Pacific & & & & \\
\hline $\begin{array}{l}\text { Australia } \\
\text { China } \\
\text { India }\end{array}$ & $\begin{array}{l}\text { Indonesia } \\
\text { Japan } \\
\text { Malaysia } \\
\text { New Zealand }\end{array}$ & $\begin{array}{l}\text { Pakistan } \\
\text { Philippines } \\
\text { Singapore } \\
\text { South Korea }\end{array}$ & $\begin{array}{l}\text { Thailand } \\
\text { Vietnam }\end{array}$ & \\
\hline $\begin{array}{l}\text { Latin America } \\
\text { Argentina } \\
\text { Brazil } \\
\text { Chile }\end{array}$ & $\begin{array}{l}\text { Colombia } \\
\text { Mexico } \\
\text { Venezuela }\end{array}$ & & & \\
\hline Canada & & & & \\
\hline
\end{tabular}

\section{Globalization}

The KOF Index of Globalization was used in the current study as a measure of globalization. This index was first introduced in 2002. This index not only measures the overall globalization but also three dimensions: economic globalization, political globalization, and social globalization. The variables and their weights that used to measure these three dimensions are listed in the Appendix. Each of these variables is transformed to an index on a scale of one to hundred. Higher values denote greater globalization according to the percentiles of the original distribution. The weights for calculating the variables are determined by the method of principal components analysis.

\section{Other variables}

Other variables used in the current study were obtained from the World Development Indicator database of The World Bank (The World Bank 2015). These variables are listed below: (1) GDP per capita, calculated by gross domestic product (GDP) divided by midyear population. (2) GDP growth rate, which is annual percentage growth rate of GDP at market prices based on constant local currency. (3) Real interest rate (\%), which is the lending interest rate adjusted for inflation as measured by the GDP deflator. ${ }^{1}$ (4) Unemployment, measured by long-term unemployment which refers to the number of people with continuous periods of unemployment extending for a year or longer, expressed as a percentage of the total unemployed. (5) Total population, which counts all 
residents regardless of legal status or citizenship. (6) Population density, which is midyear population divided by land area in square kilometers. (7) Urbanization measured by urban population (\% of total), which refers to people living in urban areas as defined by national statistical offices. (8) Education measured by school enrollment, tertiary (\% gross), which is the percentage of people who have enrolled in tertiary education level.

Panel Data Regression Methods

The data used in the current study consist of ten-year (2003-2012) data from 46 countries/regions. Panel data is a data set 'constructed from repeated cross sections over time' (Wooldridge 2003: 842). A panel data model can be used to control for variables that cannot be observed or measured, like different characteristics across countries, or variables that change over time but not across countries. Moreover, panel data can be used for multilevel or hierarchical modeling (Baltagi 2008). There are two models for the panel data analysis. One is the fixed effects model. The equation for this mode is:

$$
Y_{i t}=\alpha+\beta^{\prime} X_{i t}+u_{i t} \quad i=1,2, \ldots, n ; \quad t=1,2, \ldots, \mathrm{T}
$$

Where

$-Y_{i t}$ is the dependent variable (DV), where $i=$ entity and $t=$ time.

$-\alpha$ is the unknown intercept for each entity (n entity-specific intercepts).

$-\beta^{\prime}$ is the coefficient for that IV,

$-X_{i t}$ represents one independent variable (IV),

$-u_{i t}$ is the error.

Another is the random effects model, in which the variation across entities is assumed to be random and uncorrelated with the independent variables included in the model. The equation for this model is:

$$
Y_{i t}=\alpha+\beta^{\prime} X_{i t}+u_{i t}+\varepsilon_{i t} \quad i=1,2, \ldots, n ; \quad t=1,2, \ldots, \mathrm{T}
$$

Where

$-u_{i t}$ is the between entity error,

$-\varepsilon_{i t}$ is the within entity error.

Which model should be used depends on whether $\alpha$ is best viewed as parameters to be estimated or as outcomes of a random variable. The Hausman test was performed to determine which model should be used for the analysis.

\section{Results}

Bivariate panel data regression method was used to test $H 1$. The regression results are reported in Table 2. Model 1 showed that overall globalization index (OGI) was significantly correlated with the percentage of media expenditures in GDP $(\beta=0.03, t=4.11$, $\mathrm{p}<0.001$ ). Model 4 showed that social globalization index (SGI) was also significantly correlated with the percentage of media expenditures in GDP $(\beta=0.03, t=5.53$, $\mathrm{p}<0.001$ ). Model 2 and Model 3 showed that neither the economic globalization index (EGI) nor political globalization index (PGI) was significantly correlated with the percentage of media expenditures in GDP. 
Regression estimates of the coefficients of globalization indexes in the prediction of the percentage of media expenditures in GDP

\begin{tabular}{|l|c|c|c|c|}
\hline Constant & Model 1 & Model 2 & Model 3 & Model 4 \\
\hline OGI & $\begin{array}{c}0.48 \\
(0.95)\end{array}$ & $\begin{array}{c}1.87^{* * *} \\
(5.19)\end{array}$ & $\begin{array}{c}3.10^{* * *} \\
(5.81)\end{array}$ & $\begin{array}{c}0.75^{*} \\
(2.25)\end{array}$ \\
\hline EGI & $\begin{array}{c}0.03^{* * *} \\
(4.11)\end{array}$ & & & \\
\hline PGI & & 0.01 & & \\
\hline SGI & $(1.81)$ & -0.01 & $(-1.15)$ \\
\hline rho & 0.83 & 0.85 & 0.87 & $0.03^{* * *}$ \\
\hline R-square & 0.22 & 0.10 & 0.12 & 0.24 \\
\hline Prob $>$ F & $<0.001$ & 0.07 & 0.25 & $<0.001$ \\
\hline $\begin{array}{l}\text { Number of ob- } \\
\text { servations }\end{array}$ & 460 & 460 & 460 & 460 \\
\hline $\begin{array}{l}\text { Number of } \\
\text { groups }\end{array}$ & 46 & 46 & 46 & 46 \\
\hline $\begin{array}{l}\text { Hausman test: } \\
\text { Prob }>\text { chi2 }\end{array}$ & 0.26 & 0.09 & $<0.01$ & 0.74 \\
\hline $\begin{array}{l}\text { Model } \\
\text { Random } \\
\text { effects }\end{array}$ & $\begin{array}{c}\text { Random } \\
\text { effects }\end{array}$ & $\begin{array}{c}\text { Fixed } \\
\text { effects }\end{array}$ & $\begin{array}{c}\text { Random } \\
\text { effects }\end{array}$ \\
\hline
\end{tabular}

Notes: OGI is the overall globalization index, EGI is the economic globalization index, PGI is the political globalization index, SGI is the social globalization index. Numbers in the parentheses are $\mathrm{z}$-values for the random effects model and t-values for the fixed effects model. $* \mathrm{p}<0.05, * * \mathrm{p}<0.01, * * * \mathrm{p}<0.001$

Multiple panel data regression method was used to test $H 2$. Multiple regression analysis was performed with two steps. In the first step, globalization indexes and economic variables were entered into the regression models (Model 5-8). In the second step, population and social variables were added in to the independent variables (Model 9-12). The results are reported in Table 3 . Model 5 showed that OGI was significantly correlated with the percentage of media expenditures in $\operatorname{GDP}(\beta=0.05, t=3.22, p<0.01)$ after controlling for economic variables. Model 8 showed that SGI was also significantly correlated with the percentage of media expenditures in GDP $(\beta=0.05, \mathrm{t}=5.53, \mathrm{p}<0.001)$ after controlling for economic variables. Model 6 and Model 7 showed that neither EGI nor PGI was significantly correlated with the percentage of media expenditures in GDP after controlling for economic variables. It was also found that the log-transformed GDP (LGDP), GDP growth rate (GDPG), and unemployment rate (UNEM) had significant coefficients. LGDP and GDPG were negatively correlated with the percentage of media expenditures in GDP, while UNEM was positively correlated with the percentage of media expenditures in GDP. 
Table 3

Regression estimates of the coefficients of globalization indexes in the prediction of the percentage of media expenditures in GDP

\begin{tabular}{|c|c|c|c|c|c|c|c|c|}
\hline & Model 5 & Model 6 & Model 7 & Model 8 & Model 9 & Model 10 & Model 11 & Model 12 \\
\hline Constant & $\begin{array}{c}4.92 * * * \\
(3.76)\end{array}$ & $\begin{array}{c}7.50^{* * *} \\
(6.35)\end{array}$ & $\begin{array}{c}8.15^{* * *} \\
(8.20)\end{array}$ & $\begin{array}{c}5.01 * * * \\
(4.96)\end{array}$ & $\begin{array}{l}16.16 \\
(0.91)\end{array}$ & $\begin{array}{l}21.72 \\
(1.23)\end{array}$ & $\begin{array}{l}18.66 \\
(1.06)\end{array}$ & $\begin{array}{c}5.51 \\
(0.30)\end{array}$ \\
\hline OGI & $\begin{array}{l}0.05^{* *} \\
(3.22)\end{array}$ & & & & $\begin{array}{c}0.01 \\
(0.56)\end{array}$ & & & \\
\hline EGI & & $\begin{array}{c}0.01 \\
(0.67)\end{array}$ & & & & $\begin{array}{l}-0.01 \\
(-0.88)\end{array}$ & & \\
\hline PGI & & & $\begin{array}{l}<-0.01 \\
(-0.42)\end{array}$ & & & & $\begin{array}{l}<0.01 \\
(0.07)\end{array}$ & \\
\hline SGI & & & & $\begin{array}{c}0.05 * * * \\
(5.57)\end{array}$ & & & & $\begin{array}{l}0.03^{*} \\
(2.07)\end{array}$ \\
\hline LGDP & $\begin{array}{c}-0.65 * * * \\
(-7.26)\end{array}$ & $\begin{array}{c}-0.57 * * * \\
(-6.38)\end{array}$ & $\begin{array}{c}-0.56^{* * *} \\
(-5.76)\end{array}$ & $\begin{array}{c}-0.68 * * * \\
(-8.84)\end{array}$ & $\begin{array}{c}-0.84 * * * \\
(-6.37)\end{array}$ & $\begin{array}{c}-0.84 * * * \\
(-6.42)\end{array}$ & $\begin{array}{c}-0.83 * * * \\
(-6.25)\end{array}$ & $\begin{array}{c}-0.86 * * * \\
(-6.64)\end{array}$ \\
\hline GDPG & $\begin{array}{c}-0.06 * * * \\
(-6.71)\end{array}$ & $\begin{array}{c}-0.06 * * * \\
(-6.62)\end{array}$ & $\begin{array}{c}-0.06^{* * * *} \\
(-6.60)\end{array}$ & $\begin{array}{c}-0.05 * * * \\
(-6.43)\end{array}$ & $\begin{array}{c}-0.05 * * * \\
(-4.73)\end{array}$ & $\begin{array}{c}-0.05 * * * \\
(-4.68)\end{array}$ & $\begin{array}{c}-0.05 * * * \\
(-4.72)\end{array}$ & $\begin{array}{c}-0.05 * * * \\
(-4.70)\end{array}$ \\
\hline INTR & $\begin{array}{l}-0.01 \\
(-1.11)\end{array}$ & $\begin{array}{l}-0.01 \\
(-1.31)\end{array}$ & $\begin{array}{l}-0.01 \\
(-1.33)\end{array}$ & $\begin{array}{l}-0.01 \\
(-1.07)\end{array}$ & $\begin{array}{l}-0.01 \\
(-1.26)\end{array}$ & $\begin{array}{l}-0.01 \\
(-1.46)\end{array}$ & $\begin{array}{l}-0.01 \\
(-1.36)\end{array}$ & $\begin{array}{l}-0.01 \\
(-1.15)\end{array}$ \\
\hline UNEM & $\begin{array}{c}0.02 * * * \\
(4.73)\end{array}$ & $\begin{array}{c}0.02 * * * \\
(4.07)\end{array}$ & $\begin{array}{c}0.02 * * * \\
(4.02)\end{array}$ & $\begin{array}{c}0.03 * * * \\
(5.15)\end{array}$ & $\begin{array}{c}0.01 \\
(1.41)\end{array}$ & $\begin{array}{c}0.01 \\
(1.18)\end{array}$ & $\begin{array}{c}0.01 \\
(1.31)\end{array}$ & $\begin{array}{c}0.01 \\
(1.83)\end{array}$ \\
\hline LPOP & & & & & $\begin{array}{l}-.087 \\
(-0.81) \\
\end{array}$ & $\begin{array}{l}-1.13 \\
(-1.07)\end{array}$ & $\begin{array}{l}-1.00 \\
(-0.92)\end{array}$ & $\begin{array}{c}-0.20 \\
(-1.18)\end{array}$ \\
\hline POPD & & & & & $\begin{array}{l}<0.01 \\
(0.03)\end{array}$ & $\begin{array}{l}<0.01 \\
(0.24)\end{array}$ & $\begin{array}{l}<0.01 \\
(0.13)\end{array}$ & $\begin{array}{l}<-0.01 \\
(-0.08)\end{array}$ \\
\hline POPU & & & & & $\begin{array}{c}0.12 * * * \\
(4.55)\end{array}$ & $\begin{array}{c}0.12 * * * \\
(5.03)\end{array}$ & $\begin{array}{c}0.12 * * * \\
(4.97)\end{array}$ & $\begin{array}{l}0.09 * * \\
(3.41)\end{array}$ \\
\hline SCOE & & & & & $\begin{array}{l}<-0.01 \\
(-1.72)\end{array}$ & $\begin{array}{l}<-0.01 \\
(-1.84)\end{array}$ & $\begin{array}{c}<-0.01 \\
(1.06)\end{array}$ & $\begin{array}{l}<-0.01 \\
(-1.57)\end{array}$ \\
\hline Adj R-squared & 0.90 & 0.90 & 0.90 & 0.91 & 0.91 & 0.91 & 0.91 & 0.91 \\
\hline rho & 0.94 & 0.94 & 0.95 & 0.94 & 0.98 & 0.96 & 0.98 & 0.96 \\
\hline Prob $>$ F & $<0.001$ & $<0.001$ & $<0.001$ & $<0.001$ & $<0.001$ & $<0.001$ & $<0.001$ & $<0.001$ \\
\hline $\begin{array}{l}\text { Number of } \\
\text { observations }\end{array}$ & 247 & 247 & 247 & 247 & 192 & 192 & 192 & 192 \\
\hline $\begin{array}{l}\text { Number of } \\
\text { groups }\end{array}$ & 32 & 32 & 32 & 32 & 29 & 29 & 29 & 29 \\
\hline $\begin{array}{l}\text { Hausman test: } \\
\text { Prob > chi } 2\end{array}$ & $<0.001$ & $<0.001$ & $<0.001$ & $<0.001$ & 0.003 & $<0.001$ & $<0.001$ & 0.01 \\
\hline Model & $\begin{array}{l}\text { fixed } \\
\text { effects }\end{array}$ & $\begin{array}{l}\text { fixed } \\
\text { effects }\end{array}$ & $\begin{array}{l}\text { fixed } \\
\text { effects }\end{array}$ & $\begin{array}{l}\text { fixed } \\
\text { effects }\end{array}$ & $\begin{array}{l}\text { fixed } \\
\text { effects }\end{array}$ & $\begin{array}{l}\text { fixed } \\
\text { effects }\end{array}$ & $\begin{array}{l}\text { fixed } \\
\text { effects }\end{array}$ & $\begin{array}{l}\text { fixed } \\
\text { effects }\end{array}$ \\
\hline
\end{tabular}

Notes: OGI is the overall globalization index, EGI is the economic globalization index, PGI is the political globalization index, SGI is the social globalization index, LGDP is the log-transformed GDP, GDPG is the annual GDP growth rate, INTR is the real interest rate, UNEM is the unemployment rate, LPOP is the log-transformed population, POPD is the population density, POPU is the percentage of urban population, SCOE is the School enrollment at the tertiary level. Numbers in the parentheses are $\mathrm{z}$-values for the random effects model and $\mathrm{t}$-values for the fixed effects model.

$* \mathrm{p}<0.05, * * \mathrm{p}<0.01,{ }^{*} * * \mathrm{p}<0.001$ 
After population and social variables were entered into the models, Model 9 showed that the coefficient of OGI was non-significant after controlling for economic, population, and social variables. Meanwhile, Model 12 showed that SGI remained significantly correlated with the percentage of media expenditures in GDP $(\beta=0.03, t=2.07, p<0.05)$ after controlling for economic, population, and social variables. Model 10 and Model 11 showed that the coefficients of EGI and PGI were not significant after controlling for economic, population, and social variables.

In terms of other economic, population, and social independent variables, the logtransformed GDP per capita (LGDP) had significant and negative coefficients across Models 5-12; the annual GDP growth rate (GDPG) had significant and negative coefficients across Models 5-12; the unemployment rate (UNEM) had significant and positive coefficients across Models 5-8, but did not have significant coefficients across Models 9-12; the percentage of urban population (POPU) had significant and positive coefficients across Models 9-12.

\section{Discussion and Conclusion}

The contribution of the media economy to a national economy is one of the major macro-level research issues in media economics. Media scholars began to explore this issue long ago with the PRC (McCombs 1972). The empirical examination of the PRC received mixed findings under different circumstances. While most of the PRC studies were conducted within country boundary, several studies examined it across countries. These across-country studies suggested the PRC is not valid when applied globally. The data showed a significant variation exist across countries in terms of the contribution of media economy to national economy (Albarran 2010). Media economists need to investigate the reasons for this variation.

The current study investigated the relationship between globalization and the contribution of media economy to national economy, attempting to advance the scholarship in this regard. Different from previous studies that used proxy variables of globalization, the current study directly used globalization indexed as the independent variable. The two hypotheses both received partial support. H1 was supported when OGI and the SGI were used as the independent variables, but was not supported when EGI and PGI were used as independent variables. H2 was supported when OGI and SGI were used as independent variables after controlling for economic variables, and was supported when SGI were used as the independent variables after controlling for economic, population, and social variables. But it was not supported when OGI was used as independent variables after controlling for economic, population, and social variables.

Clark (2000) argued globalization is a process that involves the flows of people, information, ideas, capital and goods. Norris (2000) argued globalization affects many aspects of society, including economy, culture, technology, and governance. Thus, it is reasonable to argue that globalization also affects the media economy. The correlation between the overall globalization index (OGI) and the percentage of media expenditures in GDP provided evidence of this argument to some extent. However, the correlation was not robust as it became non-significant after controlling for the economic, population, and social variables. 
Globalization is a multi-dimension process upon which Keohane and Nye (2000) developed three dimensions - economic globalization, political globalization, and social globalization. The findings of the current study suggested that these three dimensions had different influence on the contribution of media economy to national economy: Economic globalization and political globalization have no significant influence, while social globalization has a significant influence.

Yang and Shanahan (2003) used the trade (percentage of GDP), and Chang and Chan-Olmsted (2005) used the foreign direct investment (percentage of GDP) to examine the influence of globalization on media economy. It is problematic to measure globalization using only one economic variable since globalization is a multi-dimension process. And one variable is also insufficient to measure economic globalization since this dimension also consists of multiple levels of economic activities. In this regard, the current study advanced the previous investigations by using a comprehensive globalization measurement.

The political globalization index used in the current study was measured by three variables that reflect the involvement into international affairs and participation in organizations. These three variables - embassies in country, membership in international organizations, and participation in the UN Security Council missions - have no inherent connection with media. This could explain why no significant correlation was found between political globalization and the percentage of media expenditures in GDP in the present study. Nevertheless, one could argue that political globalization influences media globalization, especially the expansion of international news organizations, and vice versa. To explore this relationship, a more comprehensive measure of political globalization is needed in future research.

The social globalization index used in the current study was measured by 12 variables that reflect personal contact, information flows, and cultural proximity. Eight of these 12 variables are media variables or variables that closely relate to media. This can explain why a significant correlation was found between the social globalization index and the percentage of media expenditures in GDP. This correlation was robust after controlling for economic, political, population, and social variables, suggesting social globalization has significant influence on the contribution of media economy to national economy.

The log-transformed GDP per capita (LGDP) has significant negative coefficients. This is a confounding result as significant and positive correlations were found between this variable and the percentage of media expenditures in GDP when cross section data were used in most of the ten years. However, when the time series data during this tenyear period were examined for each country, it was found that many exhibited declining or fluctuating patterns while GDP per capita would increase gradually. This might be the reason for the negative coefficients of LGDP since the results of the panel data regression also reflected the longitudinal patterns.

The negative coefficients of the annual GDP growth rate (GDPG) suggested that when economic growth rate was high the percentage of media expenditures in GDP was low. The exogenous growth model argues that poor countries have higher economic growth rates than rich countries (Solow 1956). And cross-country data also showed this convergence pattern in recent decades (Spence 2011), which is different from the diver- 
gence pattern (richer countries have higher economic growth rates than poor countries) during the nineteenth century (Jones 1981; Pomeranz 2000). The PricewaterhouseCoopers data suggested the percentages of media economy in the GDP of poor countries were lower than those of rich countries. These patterns can explain the negative coefficients of GDPG. Moreover, this result also suggested that the growth rate of the media economy was lower than that of national economy, so that, the percentage of media expenditures in GDP declined when the national economy kept growing. It contradicted the PRC argument that the percentage of media expenditures in GDP keeps constant over time. This reinforced the findings of Picard (2001), Van der Wurff, Bakker and Picard (2008), and Chang and Chan-Olmsted (2005), which suggested that PRC might not be valid when it is examined across countries.

Unemployment rate (UNEM) had negative coefficients when economic variables were added into the models. When people are unemployed, they have more leisure time. Media consumption can be heavily time consuming. Statistics showed that American adults on average spend about ten hours per day with media (U.S. Census Bureau 2011). More leisure time could induce more media consumption. But this variable became non-significant when population and social variables were added. Then, the urbanization variable, measured by urban population (\% of total), became significant. The positive correlation between urbanization and the percentage of media expenditures in GDP further supported the long-held argument that urban residents have stronger demands for media than rural residents (e.g., Park 1923; Demers 1994).

As a first attempt to examine the relationships between globalization indexes and the percentage of media expenditures in GDP, the current study contained several major limitations. First, while the empirical analyses suggested different dimensions of globalization had different influences on the percentage of media expenditures in GDP, the current study did not theoretically explore the different mechanisms through which the three dimensions of globalization affect the media economy. Although the results showed economic globalization and political globalization had no significant correlation with the percentage of media expenditures in GDP, these dimensions of globalization would inevitably affect the media economy. For example, the relaxation of international trade facilitates the flow of media products around the world. And the spread of democracy around the world facilitates the expansion of the Western media conglomerates around the world. The non-significant results should not be used to deny these mechanisms. Rather, they might be caused by the limitations of the secondary data used in the current study. For example, the measure of political globalization does not reflect the spread of democracy around the world, which should be an essential part of political globalization. In this regard, the advance of the measurement of globalization will further the exploration of the relationship between globalization and the media economy. The current study also had the limitation of generalizability. The findings were based on the data of 46 countries listed in the PricewaterhouseCoopers dataset. It should be cautious to generalize these findings globally. Even with these limitations, the current study implied that globalization influenced the contribution of the media economy to a national economy, and different dimensions of globalization had different extents of influence. These implications would further advance the examination of PRC across countries. 
NOTE

${ }^{1}$ The GDP deflator is a measure of the level of prices of all new, domestically produced, final goods and services in an economy.

\section{REFERENCES}

Albarran, A. B. 2010. The Media Economy. New York: Routledge.

Anderson, C. 2006. The Long Tail: Why the Future of Business is Selling Less of More. New York: Hyperion.

Andras, T. L., and Srinivasan, S. S. 2003. Advertising Intensity and R\&D Intensity: Differences across Industries and their Impact on Firm's Performance. International Journal of Business and Economics 2 (2): 167-176.

Ashley, R., Granger, C., and Schmalensee, R. 1980. Advertising and Aggregate Consumption: An Analysis of Causality. Econometrica 48 (5): 1149-1169.

Baltagi, B. H. 2008. Econometric Analysis of Panel Data. West Sussex: John Wiley \& Sons, Ltd.

Bergh, A., and Nilsson, T. 2010. Do Liberalization and Globalization Increase Income Inequality? European Journal of Political Economy 26 (4): 488-505.

Blank, D. M. 1962. Cyclical Behavior of National Advertising. The Journal of Business 35 (1): 14-27.

Burch, S. W., and Gordon, S. E. 1984. The Michigan Surveys and the Demand for Consumer Durables. Business Economics 19 (5): 4-44.

Chang, B. H., and Chan-Olmsted, S. M. 2005. Relative Constancy of Advertising Spending: A Cross-National Examination of Advertising Expenditure and their Determinants. $\mathrm{Ga}$ zette: The International Journal for Communication Studies 67 (4): 339-357.

Chang, C., Lee, C., and Hsieh, M. 2011. Globalization, Real Output and Multiple Structural Breaks. Global Economic Review 40 (4): 421-444.

Clark, W. C. 2000. Environmental Globalization. In Nye, J. S., and Donahue, J. D. (eds.), Governance in a Globalizing World (pp. 86-108). Washington, D.C.: Brookings Institution Press.

Collins, J., and Litman, B.R. (1984). Regulation of the Canadian cable industry: A comparative analysis. Telecommunications Policy, 8(2), 93-106.

Delia, J. 1987. Communication Research: A History. In Chaffee, S., and Berger, C. (eds.), Handbook of Communication Science (pp. 20-98). Newbury Park, CA: Sage.

Demers, D. P. 1994. Relative Constancy Hypothesis, Structural Pluralism, and National Advertising Expenditures. The Journal of Media Economics 7 (4): 31-48.

Dreher, A. 2006. Does Globalization Affect Growth? Evidence from a New Index of Globalization. Applied Economics 38 (10): 1091-1110.

Dreher, A., Gaston, N., and Martens, P. 2008. Measuring Globalization: Gauging its Consequences. New York: Springer.

Dreher, A., Gaston, N., Martens, P., and Boxem, L. V. 2010. Measuring Globalization Opening the Black Box. A Critical Analysis of Globalization Indices. Journal of Globalization Studies 1 (1): 166-185.

Duffy, M. 1991. Advertising in Demand Systems: Testing a Galbraithian Hypothesis. Applied Economics 23 (3): 485-496. 
Dupagne, M. 1994. Testing the Relative Constancy of Mass Media Expenditure in the United Kingdom. The Journal of Media Economics 7 (3): 1-14.

Dupagne, M. 1997. Beyond the Principle of Relative Constancy: Determinants of Consumer Mass Media Expenditures in Belgium. The Journal of Media Economics 10 (2): 3-19.

Emery, M., and Emery, E. 1988. The Press and America: An Interpretative History of the Mass Media. $6^{\text {th }}$ ed. Englewood Cliffs, NJ: Prentice Hall.

Ermini, B., and Santolini, R. 2014. Does Globalization Matter on Fiscal Decentralization? New Evidence from the OECD. Global Economic Review 43 (2): 153-183.

Fan, Q. 2005. Regulatory factors influencing Internet access in Australia and China: A comparative analysis. Telecommunications Policy, 29 (2-3), 191-203.

Faulhaber, G. R., and Hogendorn, C. 2000. The Market Structure of Broadband Telecommunications. Journal of Industrial Economics 48: 305-329.

Foros, O., and Kind, H. J. 2003. The Broadband Access Market: Competition, Uniform Pricing and Geographical Coverage. Journal of Regulatory Economics 23 (3): 215-235.

Goff, D.H. 2002. An assessment of the broadband media strategies of Western European telecoms. In R. G. Picard (Ed.), Media firms: Structures, operations and performance (pp. 169-189). Mahwah, NJ: Lawrence Erlbaum.

Gotz, G. 2013. Competition, Regulation, and Broadband Access to the Internet. Telecommunications Policy 37 (11): 1095-1109.

Grieves, R. 1983. The Demand for Consumer Durables. Journal of Money, Credit, and Banking 15 (3): 316-326.

Hardt, M., and Negri, A. 2000. Empire. Cambridge, MA: Harvard University Press.

Jayakar, K., and Waterman, D. 2000. The Economics of American Theatrical Movie Exports: An Empirical Analysis. The Journal of Media Economics 13 (3): 153-169.

Jones, E. 1981. The European Miracle: Environments, Economics and Geopolitics in the History of Europe and Asia. $1^{\text {st }}$ ed. Cambridge, UK: Cambridge University Press.

Keohane, R. O., and Nye, J. S. 2000. Introduction. In Nye, J. S., and Donahue, J. D. (eds.), Governance in a Globalizing World (pp. 1-44). Washington, D.C.: Brookings Institution Press.

Kim, S. 2003. The Effect of the VCR on the Mass Media Markets in Korea, 1961-1993. Journal of Asian Pacific Communication 13 (1): 59-74.

Kraemer, K. L., Ganley, D., and Dewan, S. 2005. Across the Digital Divide: AcrossCountry Multi-Technology Analysis of the Determinants of IT Penetration. Journal of the Association for Information Systems 6 (12): 409-432.

Lacy, S., and Noh, G. Y. 1997. Theory, Economics, Measurement, and the Principle of Relative Constancy. The Journal of Media Economics 10 (3): 3-16.

Langhorne, R. 2001. The Coming of Globalization: Its Evolution and Contemporary Consequences. New York: Palgrave.

Lee, C., and Chan-Olmsted, S.M. (2004). Competitive advantage of broadband Internet: A comparative study between South Korea and the United States. Telecommunications Policy 28 (9), 649-677.

Li, Q., and Reuveny, R. 2003. Economic Globalization and Democracy: An Empirical Analysis. British Journal of Political Science 36 (1): 575-601. 
Macleod, C. 2004. Adspend in G7 Countries. International Journal of Advertising 23 (4): 534-536.

Mah, J. S. 2002. The Impact of Globalization on Income Distribution: The Korean Experience. Applied Economics Letters 9 (15): 1007-1009.

Mankiw, N. G. 1985. Consumer Durables and the Real Interest Rate. The Review of Economics and Statistics 67: 353-362.

Mankiw, G. N. 2007. Macroeconomics. $6^{\text {th }}$ ed. New York: Worth Publisher.

Martens, P., and Amelung, B. 2010. On the Correlation between Globalization and Vulnerability in Times of Economic Crisis - a Statistical Analysis for Europe. Globality Studies Journal 17: 1-15.

McCombs, M. E. 1972. Mass Media in the Marketplace. Journalism Monographs, no 24. Thousand Oaks, CA: Sage Publications.

McCombs, M. E., and Eyal, C. H. 1980. Spending on Mass Media. Journal of Communication 30 (4): 153-158.

Millar, C. C. J. M., Choi, C. J., and Chen, S. 2005. Globalization Rediscovered: The Case of Uniqueness and 'Creative Industries'. Management International Review 45 (1): $121-128$.

Naatanen, A. 2015. The Impact of Economic Globalization on the Employment Policies in 19 Western Democracies from 1985 to 2010: Limited Change or Radical Shift towards Workfare? Social Science 4 (3): 700-717.

Norris, P. 2000. Global Governance and Cosmopolitan Citizens. In Nye, J. S., and Donahue, J. D. (eds.), Governance in a Globalizing World (pp. 155-177). Washington, D.C.: Brookings Institution Press.

Park, A. E. 1923. The Natural History of the Newspaper. American Journal of Sociology 29 (3): 273-289.

Picard, R. G. 2001. Effects of recessions on advertising expenditures: An exploratory study of economic downturns in nine developed nations. Journal of Media Economics 14 (1): $1-14$.

Pomeranz, K. 2000. The Great Divergence: China, Europe, and the Making of the Modern World Economy. Princeton, New Jersey: Princeton University Press.

PricewaterhouseCoopers. n.d. Global Entertainment and Media Outlook. URL: http://www. pwc.com/gx/en/industries/entertainment-media/outlook.html. Retrieved October $16^{\text {th }}$ 2015.

Quarles, R. C., and Jeffres, L. W. 1983. Advertising and National Consumption: A Path Analytic Re-Examination of the Galbraithian Argument. Journal of Advertising 12 (2): 4-33.

Rossana, R. J. 2011. Macroeconomics. New York: Routledge.

Samuelson, P. A. 1964. Economics. $6^{\text {th }}$ ed. New York: McGraw-Hill Book Company.

Shaver, M. A., and Shaver, D. 2005. Changes in the Levels of Advertising Expenditures during Recessionary Periods: A Study of Advertising Performance in Eight Countries. Paper presented at the Asian-American Academy of Advertising, Hong Kong, June.

Sohn, S. 2005. Inter-industry an intra-industry competition in satellite broadcasting: A comparative case study on the United States, Japan, England and France. Journal of Media Economics 18 (3): 167-182. 
Solow, R. M. 1956. A Contribution to the Theory of Economic Growth. Quarterly Journal of Economics 70 (1): 65-94.

Son, J., and McCombs, M. E. 1993. A Look at the Constancy Principle under Changing Market Conditions. The Journal of Media Economics 6 (2): 23-36.

Spence, M. 2011. The Next Convergence: The Future of Economic Growth in a Multispeed World. New York: Farrar, Straus and Giroux.

Swerdlow, R. A., and Blessios, V. I. 1993. A model for predicting advertising expenditures: An inter-industry comparison. International Journal of Advertising, 12(2), 143-153.

The World Bank. 2015. World Development Indicator [Datefile]. Retrieved from http://data. worldbank.org/data-catalog/world-development-indicators

U.S. Census Bureau. 2011. The 2011 Statistical Abstract. URL://www.census.gov/compen $\mathrm{dia} /$ statab/cats/information_communications/information_sector_services_media_usage. html. March 30, 2011.

Valletti, T. M., Barros, P. P., and Hoernig, S. H. 2002. Universal Service and Entry: The Role of Uniform Pricing and Coverage Constraints. Journal of Regulatory Economics 21 (2): 169-190.

Van der Wurff, R., Bakker, P., and Picard, R. G. 2008. Economic Growth and Advertising Expenditures in Different Media in Different Countries. The Journal of Media Economics 21 (1): 28-52.

Weber, W. E. 1975. Interest Rates, Inflation, and Consumer Expenditures. American Economic Review 65: 843-858.

Werner, A. 1986. Mass Media Expenditures in Norway: The Principle of Relative Constancy Revisited. In McLaughlin, M. (ed.), Communication Yearbook 9 (pp. 251-260). Beverly Hills, CA: Sage.

Wood, W. C. 1986. Consumer Spending on the Mass Media: The Principle of Relative Constancy Reconsidered. Journal of Communication 36 (2): 39-51.

Wood, W. C., and O'Hare, S. L. 1991. Paying for the Video Revolution: Consumer Spending on the Mass Media. Journal of Communication 41(1): 24-30.

Wooldridge, J. M. 2003. Introductory Econometrics: A Modern Approach. Ohio: SouthWestern College Publication.

Yang, F., and Shanahan, J. 2003. Economic Openness and Media Penetration. Communication Research 30 (5): 557-573.

Zinkina, J., Korotayev, A., and Andreev, A. I. 2013. Measuring Globalization: Existing Methods and their Implications for Teaching Global Studies and Forecasting. CampusWide Information Systems 30 (5): 321-339. 


\section{KOF Index of Globalization}

Indices and Variables

Weights

A. Economic Globalization

[36 \%]

1) Actual Flows

Trade (percent of GDP)

$(50 \%)$

Foreign Direct Investment, stocks (percent of GDP)

$(22 \%)$

$(27 \%)$

Portfolio Investment (percent of GDP)

$(24 \%)$

Income Payments to Foreign Nationals (percent of GDP)

2) Restrictions

Hidden Import Barriers

Mean Tariff Rate

$(28 \%)$

Taxes on International Trade (percent of current revenue)

$(26 \%)$

Capital Account Restrictions

B. Social Globalization

[38\%]

1) Data on Personal Contact

Telephone Traffic

$(25 \%)$

Transfers (percent of GDP)

$(3 \%)$

International Tourism

$(26 \%)$

Foreign Population (percent of total population)

$(21 \%)$

International letters (per capita)

2) Data on Information Flows

Internet Users (per 1,000 people)

$(36 \%)$

Television (per 1,000 people)

$(38 \%)$

Trade in Newspaper (percent of GDP)

3) Data on Cultural Proximity

Number of McDonald's Restaurants (per capita)

Number of Ikea (per capita)

$(44 \%)$

Trade in books (percent of GDP)

C. Political Globalization

Embassies in Country

Membership in International Organizations

Participation in U.N. Security Council Missions 